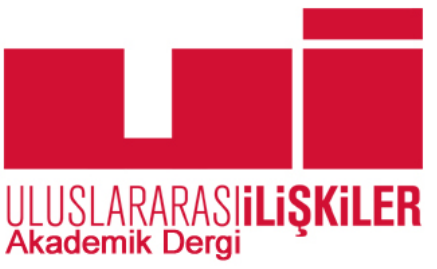

Yayın ilkeleri, izinler ve abonelik hakkında ayrıntılı bilgi:

E-mail: bilgi@uidergisi.com.tr

Web: www.uidergisi.com.tr

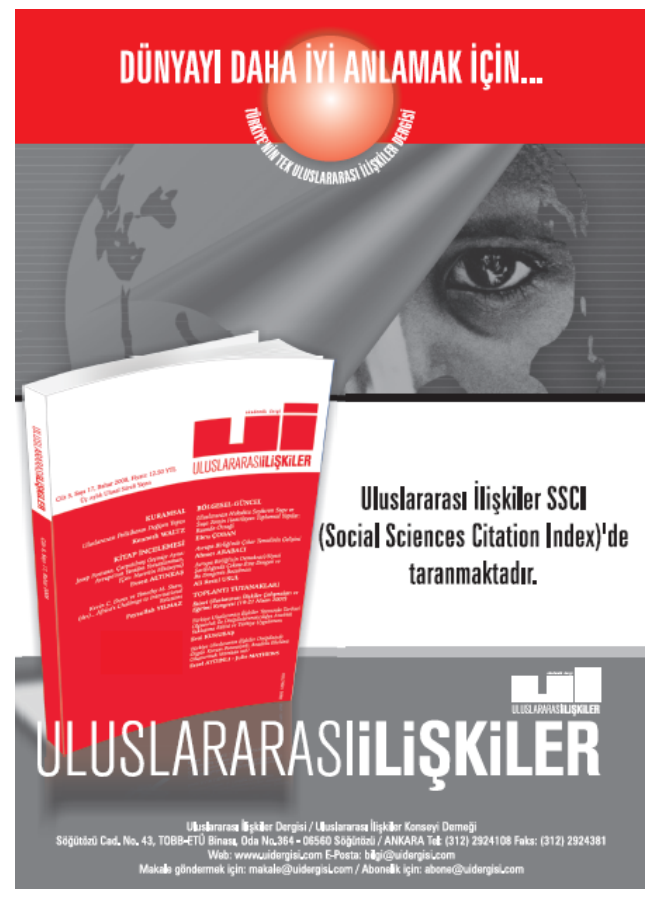
Eski Savaş, Yeni Strateji: Rusya'nın
Yirmibirinci Yüzyıldaki Hibrit Savaş Doktrini ve Ukrayna Krizi'ndeki Uygulamast

\author{
Ali Nedim KARABULUT * \\ *Doktora Öğrencisi, Siyaset Bilimi ve Kamu Yönetimi Bölümü, \\ Bilkent Üniversitesi
}

Bu makaleye atıf için: Karabulut, Ali Nedim "Eski Savaş, Yeni Strateji: Rusya'nın Yirmibirinci Yüzyıldaki Hibrit Savaş Doktrini ve Ukrayna Krizi'ndeki Uygulamasi", Uluslararası Illişkiler, Cilt 13, Say1 49, 2016, s. 25-42.

Bu makalenin tüm hakları Uluslararası İlişkiler Konseyi Derneği'ne aittir. Önceden yazılı izin alınmadan hiç bir iletişim, kopyalama ya da yayın sistemi kullanılarak yeniden yayımlanamaz, çoğaltılamaz, dağıtılamaz, satılamaz veya herhangi bir şekilde kamunun ücretli/ücretsiz kullanımına sunulamaz. Akademik ve haber amaçlı kısa alıntılar bu kuralın dışındadır.

Aksi belirtilmediği sürece Uluslararası Illişkiler'de yayınlanan yazılarda belirtilen fikirler yalnızca yazarına/yazarlarına aittir. UİK Derneğini, editörleri ve diğer yazarları bağlamaz. 


\title{
Eski Savaş, Yeni Strateji: Rusya'nın Yirmibirinci Yüzyıldaki Hibrit Savaş Doktrini ve Ukrayna Krizi’ndeki Uygulaması
}

\author{
Ali Nedim KARABULUT \\ Doktora Öğrencisi, Siyaset Bilimi ve Kamu Yönetimi Bölümü, Bilkent Üniversitesi, Ankara. E-posta: anedim@bilkent.edu.tr
}

\section{ÖZET}

Şubat-Mart 2014'te Rusya Federasyonu, Ukrayna'ya bağlı Kırım’ı bilinen savaş taktikleri yerine ağırlıklı olarak Ukrayna’nın iç güçlerini kullanarak işgal etmiştir. Bu uygulama, Soğuk Savaş sonrası güvenlik ortamında kalıcı değişikliklere işaret etmektedir. Rusya’nın Ukrayna krizi süresince kullandığı taktikler, askerî ve sivil aktörlerin ortak politik amaç için koordineli kullanımını ve hedef ülkedeki iç dinamiklerin manipüle edilmesini öngörmektedir. NATO'nun hazırlıksız olduğu ve hibrit savaş olarak adlandırılan bu savaş türü, Ukrayna ile benzer özellikler taşıyan NATO ülkelerinde endişe oluşturmaktadır. Bu makalede Rusya’nın hibrit savaşı nasıl algıladığı ve Ukrayna krizinde nasıl uyguladığı incelenerek bu yeni savaş türünün genel özelliklerine yönelik değerlendirmeler yapılacaktır.

Anahtar Kelimeler: Hibrit Savaş, Rusya, Ukrayna, Kırım.

\section{Old War, New Strategy: Russian Doctrine of Hybrid Warfare for the Twenty First Century and Its Implementation during the Crisis in Ukraine}

\begin{abstract}
In February-March 2014, Russian Federation invaded Crimean region of Ukraine not by using any regular war technique, but rather by exploiting Ukraine's internal powers. This application may denote permanent changes in post-Cold War security environment. Russian tactics require orchestrated use of military and non-military actors and manipulation of internal powers inside the targeted country to achieve a common political objective. This new war technique, commonly referred to as hybrid warfare, is not something NATO has prepared itself for, and hence created concerns for NATO allies, which have similar characteristics as Ukraine. This article will explore general characteristics of hybrid warfare by examining how Russia understands it and how she implemented it in Ukraine.
\end{abstract}

Keywords: Hybrid Warfare, Russia, Ukraine, Crimea. 
"Zafer kazanan komutanlar önce kazanır ve sonra savaşa girer. Kaybedenler ise önce savaşa girer ve sonra kazanmaya çalı̧ır."

Sun-Tzu ${ }^{1}$

\section{Giriş}

Soğuk Savaş sonrasında Batı güvenlik konsepti, düzenli ordulara sahip ülkeler yerine asimetrik etki oluşturabilen düzensiz silahlı grupları referans olarak almış ve güvenlik algılamasını değiştirmiştir. ${ }^{2}$ Gelişen teknolojik imkânlarla beraber etkinlikleri artan asimetrik tehditler, konvansiyonel üstünlüğe sahip ülkelerin tehdit sıralamasında öncelik kazanmıştır. Asimetrik savaşta daha güçsüz durumdaki aktörün daha güçlü olana kendi gücünün üzerinde zarar vermesi, kullanılan kaynakla bu kaynağın oransal potansiyelinin normalde oluşturacağının üzerinde etki yapması temel hedeftir. Ancak bu tanımlama yapılırken asimetrik etkilerin temel olarak hiçbir ülkeye bağlı olmayan düzensiz silahlı gruplar tarafından uygulanacağı varsayılmıştır. Oysa Ukrayna krizi ve Kırım’ın ilhakı sırasında Rusya tarafından uygulanan taktikler, asimetrik savaşın sadece küçük çaplı silahlı gruplar tarafından değil, yüksek askerî güce sahip devletler tarafından da temel savaş stratejisi olarak benimsenebileceğini göstermiştir. Ülkelerin sahip oldukları imkânların daha fazla olması sebebiyle kullanılan araçların ve uygulanan yöntemlerin kapsam ve çeşitliliğinde önemli artış olmuştur.

Hibrit Savaş, modern teknolojinin ve iletişim imkânlarının getirdiği yeniliklerden faydalanarak düzenli ve düzensiz güçlerin, askerî ve sivil unsurların, alışılmış ve alışılmadık taktiklerin bir arada kullanılmasını içermekte ve günümüz krizlerinin tanımlanması için uygun düşmektedir. Hibrit savaş, daha önce literatürde sık kullanılan sınırlı savaşla bir tutulmakta ya da onun geliştirilmiş hâli olarak da nitelendirilmektedir. ${ }^{3}$ Hibrit savaşın bir nevi sınırlı savaş olduğu doğrudur, çünkü ülke ya da ülkeler tüm askerî güçlerini kullanarak karşı karşıya gelmemektedir. Bununla birlikte asıl fark, sınırlı da olsa öncelikli olarak kullanılan askerî güç unsurlarının yerini diğer araçların almasıdır. Hibrit savaş konsepti, sınırlı savaştan çok daha fazlasını içermektedir.

\section{Hibrit Savaşın Tanımı ve Tarihçesi}

Asimetrik savaşın düzensiz gruplar yerine ülkeler tarafindan uygulanması olarak adlandırabilecek modern savaşa ne isim verileceği konusunda tam bir görüş birliği bulunmamaktadır. Aynı ya da benzer konuları ifade etmek amacıyla politik savaş ${ }^{4}$, geleneksel olmayan savaş ${ }^{5}$, lineer olmayan savaş ${ }^{6}$, gerilla jeopolitiği ${ }^{7}$ gibi isimler kullanılabilmektedir. Bu farklılıklara rağmen, özellikle Rusya'nın 2013-2014

1 Sun-Tzu, The Art of War, Bölüm 4/12, (çev. Sonshi Grup), https://www.sonshi.com/original-the-art-of-war-translationnot-giles.html (Erişim Tarihi 4 Eylül 2015).

2 Rod Thornton, Asymmetric Warfare: Threat and Response in the 21st Century, Cambridge, Polity Press, 2007, s.1-8.

3 Lawrence Freedman, "Ukraine and the Art of Limited War", Survival: Global Politics and Strategy, Cilt 56 No.6, Aralık 2014-Ocak 2015, s.7-38.

4 George Kennan, 269. Policy Planning Staff Memorandum (ABD Dıșişleri Bakanlığı Politika Planlama Kâğıdı 269), 4 Mayıs 1948, http://academic.brooklyn.cuny.edu/history/johnson/65ciafounding3.htm (Erişim Tarihi 14 Mart 2016); Max Boot ve Michael Doran, "Political Warfare", Policy Innovation Memorandum No.33 (ABD Dış İlişkiler Konseyi Politika Geliştirme Kâğıdı No.33), Haziran 2013, http://www.cfr.org/wars-and-warfare/political-warfare/p30894 (Erişim Tarihi 14 Mart 2016).

5 David Maxwell, “Taking a Spoon to a Gunfight”, War on the Rocks, 2 Nisan 2014, http://warontherocks.com/2014/04/ taking-a-spoon-to-a-gunfight/ (Erişim Tarihi 14 Mart 2016).

6 Bret Perry, "Non-Linear Warfare in Ukraine: The Critical Role of Information Operations and Special Operations", Small Wars Journal, 14 Ağustos 2015, http://smallwarsjournal.com/printpdf/27014 (Erişim Tarihi 14 Mart 2016).

7 Mark Galeotti, "Putin, Ukraine and Asymmetric Politics”, bne Intellinews, 14 Nisan 2014, http://www.intellinews.com/ comment-putin-ukraine-and-asymmetric-politics-500399277/?source=russia\&archive=bne (Erişim Tarihi 14 Mart 2016). 
yılları arasında en yoğun dönemini yaşayan Ukrayna krizi sırasındaki uygulamalarıyla tekrar gündeme gelen hibrit savaş teriminin diğer terimlere nispeten daha fazla yaygınlık kazandığı görülmektedir.

"Hibrit" terimi, normalde bir araya gelmeyen iki farklı unsurun alışılagelmişin dışında bir araya gelmesini ifade etmektedir. Savaş yöntemi olarak kullanıldığında düzenli orduyla beraber düzensiz silahlı grupların, askerle beraber sivil halkın, askerî güçle beraber askerî olmayan (ekonomik, sosyal, politik, vb.) imkânların, sıcak çatışmayla beraber şiddet içermeyen yöntemlerin kullanılması kastedilmektedir. Frank R. Hoffman, hibrit tehditleri, düşmanın "konvansiyonel silahlar, alışılagelmişin dışında taktikler, terörizm ve hukuk dışı faaliyetlerin amaca yönelik harmanlanmış şeklini kendi politik amaçlarına ulaşmak için aynı harekât ortamında ve zaman diliminde kullanması" olarak ifade etmektedir.8 Peter Mansoor, hibrit savaşı "Ortak bir politik amacı gerçekleştirmek üzere konvansiyonel askerî kuvvetler ile düzensiz güçlerin (gerilla, asiler ve teröristler) ortak kullanımı” şeklinde tanımlamaktadır. ${ }^{9}$ Oxford Savaş El Kitabı ise ülkeler tarafından düzenli ordular kullanılarak icra edilen büyük çaplı ve düzenli/geleneksel (regular/conventional) savaşlar ile silahlı gruplar tarafından gerilla taktikleri kullanılarak yapılan küçük çaplı ve düzensiz (irregular) savaşın karışımı olarak tanımlamakta ve bu ikisi arasındaki ayırımın artık netliğini kaybettiğini ifade etmektedir. ${ }^{10}$ Ancak bu tanımlamaların, hibrit savaşı sadece şiddet içeren faaliyetlerle sınırlandırdığı görülmektedir. Yaygın kullanılan biçimiyle bu tanımın içine benzer amaçlarla kullanılan ve kullanılma potansiyeli olan pek çok unsuru ve özellikle şiddet içermeyen halk olaylarını, ekonomi ve finans alanlarındaki faaliyetleri, açıktan veya üstü kapalı olarak sivil toplum örgütleri ile işçi sendikalarının kullanılmasını, muhtelif politik unsurların cepheye sürülmesini, dezenformasyon savaşında sahte internet sitelerinin ya da ısmarlama gazete makalelerin kullanılmasını da dâhil etmek uygun olacaktır. Hibrit savaş kuramı, bu tür şiddet içermeyen faaliyetler dişarıda bırakıldığı takdirde modern savaşı tanımlamada yetersiz kalmaktadır. Bu yetersizlik, özellikle yakın zamanda meydana gelen çatışmalar incelendiğinde daha belirgin şekilde ortaya çıkmaktadır. Ukrayna krizi bu açıdan önemli bir örnek teşkil etmektedir. Zira bu krizde alışılagelmiş simetrik ve asimetrik faaliyetlerin yanı sıra şiddet içermeyen yöntemlerin devlet eliyle kullanıldığı görülmüştür. Çalışma, Ukrayna krizi ve Rusya’nın bu kriz sırasındaki uygulamaları inceleyerek hibrit savaşın genel özellikleri ortaya koymayı amaçlamaktadır.

Hibrit savaş ifadesi, özellikle 2006 yılındaki Lübnan Savaşı sırasında Hizbullah’ın İsrail’e karşı uyguladığı gerilla ve konvansiyonel taktiklerin karışımını tarif etmek amacıyla kullanılmaya başlamıştır. ${ }^{11}$ Bu savaşta Hizbullah, gerilla taktikleriyle birlikte bazı konvansiyonel savaş uygulamalarını kullanarak kendisinden çok daha güçlü İsrail ordusunu şaşırtmayı başarmıştır. ${ }^{12}$ Bununla beraber hibrit savaşın tamamıyla yeni bir savaş türü olduğu ve bu sebeple savaş konusundaki eski kuramların geçerliliğini yitirdiği konusunda farklı görüşler vardır. "Eski” ve "yeni” savaş arasındaki farkları ve karşıt görüşleri detaylı şekilde inceleyen Karaosmanoğlu, sonuçta temelleri Clausewitz’e dayanan

8 Frank Hoffman, “On Not-So-New Warfare: Political Warfare vs Hybrid Threats”, War on the Rocks, 28 Temmuz 2014, http://warontherocks.com/2014/07/on-not-so-new-warfare-political-warfare-vs-hybrid-threats/ (Erişim Tarihi 23 Temmuz 2015).

9 Peter R. Mansoor, “Introduction: Hybrid Warfare in History”, Williamson Murray ve Peter R. Mansoor (der.), Hybrid Warfare: Fighting Complex Opponents from the Ancient World to the Present, New York, Cambridge University Press, 2012, s.2.

10 Rob de Wijk, "Hybrid Conflict and the Changing Nature of Actors", Julia Lindley-French ve Yvew Boyer (der.), The Oxford Handbook of War, Oxford, Oxford University Press, 2012, s.358-372.

11 Freedman, "Ukraine and the Art of Limited War", s.10,11; Frank Hoffman, "Conflict in the 21st Century: The Rise of Hybrid Wars", Potomac Institute for Policy Studies, Arlington, VA, Aralık 2007, http://www.potomacinstitute.org/ images/stories/publications/potomac_hybridwar_0108.pdf (Erişim Tarihi 15 Haziran 2015); Alex Deep, "Hybrid War: Old Concept, New Techniques”, Small Wars Journal, 2 Mart 2015, http://www.isn.ethz.ch/Digital-Library/ Articles/Detail/?lng=en\&id=189134\#_edn1 (Erişim Tarihi 27 Temmuz 2015).

12 Freedman, "Ukraine and the Art of Limited War", s.11; Greg Grant, "Hybrid Wars", Government Executive, Cilt 40 Say1 5, 1 Mayıs 2008, http://www.govexec.com/magazine/features/2008/05/hybrid-wars/26799/ (Erişim Tarihi 14 Haziran 2015); Hoffman, "Conflict in the 21 st century". 
klasik kavramsal çerçevenin büyük ölçüde geçerliliğini koruduğu sonucuna varmıştır. ${ }^{13}$ Ona göre yeni savaştaki değişiklikler, savaşın doğasını etkileyecek derinlikte değildir. ${ }^{14}$ Benzer şekilde Mansoor da savaşın doğasının değil, "kuvvetlerin onu icra etme şeklinin" değiştiğini ifade etmektedir. ${ }^{15}$ Tarihsel olaylar, Mansoor ve Karaosmanoğlu'nun tezlerini destekler niteliktedir çünkü benzer taktikler tarih boyunca uygulanmıştır. Örneğin Birinci Dünya Savaşı’nda İngilizler tarafından Osmanlı Devleti’ne karşı yürütülen bütünleşik faaliyetler, hibrit savaşın tipik bir örneği olarak gösterilebilir. ${ }^{16}$ M.Ö. Beşinci Yüzyıldaki Peloponez Savaşı ${ }^{17}$ Roma ordularının Germen kabileleri yok etmek için yürüttüğü faaliyetler, ${ }^{18}$ Amerikan Kolonilerinin Amerikan Devrimi sırasındaki faaliyetleri ve sonrasında Amerikan İç Savaşı'nda uygulanan taktikler, ${ }^{19}$ Napolyon Savaşlarında İngiliz, Fransız ve İspanyollar arasındaki çatışmalar, ${ }^{20}$ Fransa-Prusya Savaşı'nda Prusya kuvvetlerinin uyguladığı taktikler ${ }^{21}$ ve Japonya'nın 2'nci Dünya Savaşı öncesinde Çin'deki faaliyetleri ${ }^{22}$ de aynı kapsamda değerlendirilmektedir. Daha güncel örnekler arasında ise 2006 yılında Lübnan'da yaşanan çatışmalara ilave olarak Afganistan ve Irak Savaşları sayılmaktadır. ${ }^{23}$ Bu gibi tarihsel örnekler, hibrit savaşın az rastlanılan değil, tam tersine belki de topyekûn savaştan saha sık rastlanılan bir savaş türü olduğunu göstermektedir. Dolayısıyla hibrit savaşların yeni olmadığı ancak farklı olduğu, zamanın ve teknolojinin sunduğu imkânların yardımıyla kullanılan yöntemlerin çeşitliliğinin ve etkinliğinin arttığı sonucuna varmak uygun olacaktır. Bütün bu örneklerde ortak olan ve hibrit savaşın temel karakteristiği olarak sayılabilecek bir husus, muhtelif kuvvetlerin bir araya getirilmesi ve aynı harekât ortamında eş zamanlı olarak kullanılmasıdır. ${ }^{24}$ Son olarak Suriye'de yaşanan kriz, çok yönlü ve aktörlü bir hibrit savaşın yoğun olarak uygulandığı bir harekât ortamının özelliklerini göstermektedir. ${ }^{25}$

Bugün "hibrit savaş” ya da "hibrit tehditler” teriminin resmî söyleme de yerleştiği görülmektedir. 2011 yılında NATO Dönüşüm Komutanlığı tarafından yayımlanan bir raporda hibrit tehdit, "terörizm, göç, korsanlık, yolsuzluk, etnik çatışma, vb. çok geniş alandaki düşmanca durum ve faaliyetleri kapsayan bir şemsiye terim" olarak nitelendirilmiştir. ${ }^{26}$ Aynı rapor, yeni olan hususun bu faaliyetlerin geçmişte

13 Ali L. Karaosmanoğlu, "Yirmibirinci Yüzyılda Savaşı Tartışmak: Clausewitz Yeniden”, Uluslararası İlişkiler, Cilt 8, Sayı 29 (Bahar 2011), s.5-25. Karaosmanoğlu’nun makalesinde atıfta bulunduğu karşıt görüşler için bkz. Martin van Creveld, The Transformation of War, New York, The Free Press, 1991; Mary Kaldor, New and Old Wars: Organized Violence in a Global Era, Oxford, Polity Press, 1999; Ken Booth, Theory of World Security, Cambridge, Cambridge University Press, 2007; John Keegan, A History of Warfare, New York, Vintage Books,1993; Hew Strachan ve Andreas Herberg-Rothe (der.), Clausewitz in the Twenty-First Century, Oxford, Oxford University Press, 2007; Antulio J. Echevarria II, Clausewitz and Contemporary War, Oxford University Press, 2007; Isabelle Duyvesteyn ve Jan Angstrom (der.), Rethinking the Nature of War, London, Frank Cass, 2006; Herfried Münkler, The New Wars, Cambridge, Polity Press, 2005.

14 Karaosmanoğlu, "Yirmibirinci Yüzyılda Savaşı Tartışmak", s.5,6.

15 Mansoor, "Introduction”, s.3.

16 Ibid., s.6,7.

17 Ibid., s.3,4.

18 James Lacey, “Conquering Germany: A Province Too Far”, Murray ve Mansoor, Hybrid Warfare, s.2-42.

19 Williamson Murray, “The American Revolution: Hybrid War in America’s Past”, Murray ve Mansoor, Hybrid Warfare, s.72-103; Deep, "Hybrid War".

20 Deep, "Hybrid War".

21 Marcus Jones, "Fighting This nation of liars to the very end: The German Army in the Franco-Prussian War, 1870-1871", Murray ve Mansoor, Hybrid Warfare, s.171-198.

22 Noboru Yamaguchi, "An Unexpected Encounter with Hybrid Warfare: The Japanese Experience in North China, $1937-$ 1945”, Murray ve Mansoor, Hybrid Warfare, s.225-253.

23 Mansoor, "Introduction”, s.10-12; Williamson Murray, “Conclusion: What the Past Suggests?", Murray ve Mansoor, Hybrid Warfare, s.289-308.

24 Frank G. Hoffman, "Hybrid Warfare and Challenges", Joint Forces Quarterly, Say1 52, 2009, s.34-39.

25 Dexter Filkins, “The Shadow Commander”, The New Yorker, 30 Eylül 2013, http://www.newyorker.com/ magazine/2013/09/30/the-shadow-commander (Erişim Tarihi 1 Temmuz 2015).

26 Sascha-Dominik Bachmann, Håkan Gunneriusson, "Hybrid Wars: The 21st Century's New Threats to Global Peace 
olduğu gibi rastlantısal değil, "düşmanlar tarafından uzun vadeli politik hedeflerin gerçekleşmesi için kullanılması" olduğunu ifade etmektedir. ${ }^{27}$ Ukrayna krizinden sonra bu kullanım daha da yaygınlaşmıştır. NATO eski Genel Sekreteri Anders Fogh Rasmussen, Rusya’nın Ukrayna’da yürüttüğü kampanyayı açıkça hibrit savaş olarak nitelendirmiş ve tanımını “Ukrayna’nın yeni hükümetini yıpratmak ve Doğu Ukrayna'daki Rus etkisini devam ettirmek için hesaplanarak uygulanan askerî operasyonlar, gizli operasyonlar ve yoğun dezenformasyon faaliyetlerinin bütünü” şeklinde yapmıştır. ${ }^{28}$ Litvanya Savunma Bakanlığı, kendi halkını benzer faaliyetlere karşı uyarırken aynı terimi kullanmıştır. ${ }^{29}$ ABD Savunma Bakanlığı’nın 2006 ve 2010 yıllarında yayımladığı dört yıllık Savunma Gözden Geçirme Dokümanlarında ve eski Savunma Bakanı Robert Gates'in konuşmalarında aynı ifadeye yer verilmiştir. ${ }^{30}$

Hibrit savaş konseptinin yakın zamana kadar gündemde olan etki odaklı yaklaşım konseptine göre ne kadar yenilik getirdiği konusunda farklı görüşler mevcuttur. İki konseptin farklı olduğunu iddia eden Mansoor’a göre etki odaklı yaklaşımdan hibrit savaşa geçişteki dönüm noktası 2006 ve 2008 yıllarındaki Lübnan krizleridir. Yazar, İsrail'in 2006 Lübnan Savaşı’nda başarılı olamamasını etki odaklı yaklaşımın çökmesi olarak değerlendirmekte, daha sonra 2008 yılında Gazze çatışmasındaki başarısını ise hibrit savaş yaklaşımını benimsemesine bağlamaktadır. ${ }^{31}$ Ancak bu görüş, etki odaklı yaklaşımın uygulanmasında ağırlıklı olarak düzenli ordunun kullanılacağı varsayımına yönelik bir eleştiri gibi gözükmektedir. Oysa etki odaklı yaklaşım, karşı tarafta oluşturulmak istenen etkinin belirlenmesini müteakip bu etkiyi oluşturacak en uygun aracın kullanılmasını öngörmektedir ve bu araçlar askerî, politik, ekonomik, sosyal, vb. alanlarda veya bunların bileşimleri şeklinde olabilir. ${ }^{32}$ Etki odaklı yaklaşımla çok yakından alakalı bir konsept olan ağ odaklı yaklaşım ise düşmanı iç içe geçmiş sistemler bütünü olarak görmekte ve oluşturulacak etkinin bu sistemlerin birbiriyle olan etkileşimini dikkate alarak hesaplanmasını öngörmektedir. ${ }^{33}$

$\mathrm{Bu}$ yönüyle düşünüldügünde hibrit savaş, "etki odaklı ve ağ merkezli yaklaşımın geliştirilerek daha ileri seviyeye getirilmiş şekli” olarak yorumlanabilir. Dolayısıyla şiddet içermeyen ekonomik, psiko-sosyal, enformatik, vb. alanlardaki faaliyetlerin de aynı kapsama dâhil edilmesi gerekmektedir. Daha önce belirtildiği gibi hibrit savaşı düzenli ve düzensiz ordular tarafından icra edilen simetrik ve asimetrik faaliyetlerden ibaret görmek, onun kapsamını daraltmak ve modern çatışmaları bütün yönleriyle kapsayabilme kapasitesini azaltmak anlamına gelecektir. Rusya'nın yeni savaş kuramı ve 2013-2015 yılları arasında yoğun olarak yaşanan Ukrayna krizindeki uygulamaları incelendiğinde bu durum daha net görülecektir.

And Security", Scientia Militaria - South African Journal of Military Studies, Cilt 43 Say1 1, 20 Mayıs 2015, s.77-98.

27 Ibid., s.79.

28 Mark Landler ve Michael R. Gordon, “NATO Chief Warns of Duplicity by Putin on Ukraine”, The New York Times, 8 Temmuz 2014, eski NATO Genel Sekreteri Anders Fogh Rasmussen ile görüşme, http://www.nytimes. com/2014/07/09/world/europe/nato-chief-warns-of-duplicity-by-putin-on-ukraine.html?_r=1 (Erişim Tarihi 12 Haziran 2015).

29 Maciej Bartkowski, "Nonviolent Civilian Defense to Counter Russian Hybrid Warfare", Beyaz Kitap Gov1501, The Johns Hopkins University Center for Advanced Governmental Studies, Washington D.C., 2015, http://advanced.jhu. edu/academics/graduate-degree-programs/global-security-studies/program-resources/publications/white-papermaciej-bartkowski/ (Erişim Tarihi 19 Eylül 2015).

30 Hoffman, "On Not-So-New".

31 Mansoor, "Introduction", s.15.

32 Edward A. Smith, "Effects-Based Operations: Applying Network Centric Warfare in Peace, Crisis, and War”, US DoD Command and Control Research Program (CCRP), 2003, http://www.au.af.mil/au/awc/awcgate/ccrp/ebo_smith. pdf (Erişim Tarihi 29 Ağustos 2015).

33 John A. Warden, “The Enemy as a System”, Airpower Journal, Bahar 1995, http://www.airpower.maxwell.af.mil/ airchronicles/apj/apj95/spr95_files/warden.htm (Erişim Tarihi 8 Eylül 2015). 


\section{Rus Yaklaşımı}

Rusya'nın "maskirovka" (kamuflaj, gizleme ve aldatma) stratejisi yeni bir konu başlığı değildir. 12 Ekim 1983 tarihli ve "Çok Gizli” gizlilik derecesine sahip 108 no.lu ABD Ulusal Direktifi, Rusların kapsamlı bir program hâlinde uyguladıkları bu faaliyetler konusunda bilgileri içermektedir. ${ }^{34}$ Bugün Rusya'nın benimsediği hibrit savaş stratejisi kapsamında "maskirovra" doktrinin geliştirilmiş hâlinin yanı sıra fiziksel güç veya onun kullanılması tehdidi, yoğun propaganda, makul inkâr edilebilirlik ve sivil, şiddet içermeyen halk olayları sayılabilir. ${ }^{35}$

Rusya'nın hibrit savaş konseptinin resmî altyapısı, Rus Hükümetinin 2007 tarihli Dış Politika Gözden Geçirme Dokümanı ve 2009 tarihli Ülke Güvenliği Gözden Geçirme Dokümanı gibi politik üst seviye dokümanlarla hazırlanmış ve yine 2009 yılında onaylanan Yurt dışında Yaşayan Rus Kökenli Vatandaşlara Yönelik Federal Kanun ile desteklenmiştir. ${ }^{36}$ Rusların Yirmibirinci Yüzyılda hedeflerini nasıl gerçekleştirmeyi planladığına yönelik önemli detaylar ise, 25 Ocak 2013’te Rus Askeri Bilimler Akademisi'nin yıllık genel toplantısında Genelkurmay Başkanı Valery Gerasimov tarafından yapılan konuşmada ortaya çıkmıştır. Gerasimov, konuşmasında özellikle Orta Doğu’daki bazı çatışmalarda savaşla barış ya da üniformalı personel ile gizli operasyonlar arasındaki farkın kapandığına dair örnekler vermiş, askerî yöntemlerin askerî olmayan yöntemlerle beraber kullanıldığında başarılı olduğunu belirtmiş ve askerî olmayan yöntemlere örnek olarak politik, ekonomik, iletişim, insanî ve diğer alanları saymıştır. ${ }^{37} \mathrm{Bu}$ faaliyetlerin gizli ve dolayısıyla inkâr edilebilecek operasyonlarla desteklenebileceğini, hatta barışı destekleme adı altında icra edilebileceğini belirtmiştir. Özellikle modern iletişim kanallarının kullanılmasının önemine dikkat çekmiş ve tüm bu çabalara ilave olarak yerel halkın profesyonel fakat gizli askerî unsurlar kullanılarak ayaklandırılabileceğini ifade etmiştir. ${ }^{38}$

Gerasimov, yeni doktrinin ayrıntıların 27 Şubat 2013'te yayımlanan "The Value of Science in Prediction", başlıklı makalede daha detaylı bir biçimde ele almaktadır. ${ }^{39}$ Makalede yer alan ve Rusya'nın modern savaş ortamını nasıl gördüğüne ışık tutan temel özellikler aşağıdaki gibi sıralanabilir:

1. Öncelikle Gerasimov, savaşla barış arasındaki çizginin inceldiğini, hatta ortadan kalktığını, savaşların artık açıkça deklare edilmediğini ve alışılmadık yöntemlerle devam ettiğini ifade etmektedir.

2. Diğer bir önemli husus ise şiddet içermeyen bazı yöntemlerin arzu edilen sonuca ulaşmada daha etkili olabilme potansiyelinin teyit edilmesidir. Rus doktrininin Arap Baharından etkilendiği ve ders aldığı açıktır. Her şeyin normal yürüdügü düşünülen bir ülkenin bir anda iç savaşın eşiğine geldiği, sarsılmaz sanılan yönetimlerin kısa sürede silindiği görülmüştür. Gerasimov, yaşanan olayların belki de tam anlamıyla "Yirmibirinci Yüzyılın tipik savaşşekli”

34 ABD Ulusal Güvenlik Direktifi No.108 (National Security Decision Directive No.108), 12 Ekim 1983, Federation of American Scientists: http://fas.org/irp/offdocs/nsdd/nsdd-108.pdf (Erişim Tarihi 17 Eylül 2015).

35 Bartkowski, "Nonviolent Civilian Defense", s.8.

36 NATO StratCom CoE Raporu, "Analysis of Russia's Information Campaign Against Ukraine”, NATO Stratejik İletişim Mükemmeliyet Merkezi (NATO StratCom COE) Raporu, Riga, Latvia, 2014, http://www.stratcomcoe.org/ /media/ SCCE/NATO_PETIJUMS_PUBLISKS_29_10.ashx (Erişim Tarihi 25 Ağustos 2015).

37 Roger McDermott, “Gerasimov Unveils Russia’s ‘Reformed’ General Staff”, Eurasia Daily Monitor, Cilt 11 No.27, 11 Şubat 2014, http://www.jamestown.org/single/?tx_ttnews[tt_news]=41951\&no_cache=1\#.VghFNZc-49k (Erişim Tarihi 4 Temmuz 2015).

38 Ibid.

39 Valery Gerasimov, “The Value of Science in Prediction”, Military-Industrial Kurier, Cilt 8 No.476, 27 Şubat 2013, http:// www.vpk-news.ru/articles/14632 (Erişim Tarihi 23 Haziran 2015); Mark Galeotti, "The 'Gerasimov Doctrine' and Russian Non-Linear War”, Moscow's Shadows (internet blog), 6 Temmuz 2014, https://inmoscowsshadows.wordpress. com/2014/07/06/the-gerasimov-doctrine-and-russian-non-linear-war/ (Erişim Tarihi 6 Ağustos 2015). 
olduğunu, yıkıcı etkileri ve verdiği zayiat açısından sosyal, ekonomik ve politik sonuçları göz önüne alındığında bu krizlerin sıcak savaşlardan geri kalmadığını söylemektedir. ${ }^{40}$ Dolayısıyla "askerî olmayan yöntemler politik ve stratejik hedefleri gerçekleştirmede daha etkili olmaya başlamış, hatta askerî yöntemlerin önüne geçmiştir" ${ }^{4}$.

3. Gerasimov, askerî olmayan araçlar kapsamında politik, ekonomik, bilgi/iletişim, insanî ve diğer araçları saymakta, bunların sivil halkın protesto gücüyle beraber kullanılmasının etkili olacağını belirtmektedir. Özellikle ülke içindeki sivil unsurların kullanımının kritik olduğu değerlendirilmektedir.

4. Ayrıca tüm bu faaliyetlerin, gizli bir şekilde askerî güçle desteklenmesi gerekmektedir. Askerî gücün açık kullanımı ancak krizin son safhalarına doğru ve kesin sonuç almak maksadıyla, barışı koruma veya krizi önleme kapsamında gerçekleştirilmelidir.

5. Bu tür bir savaşı destekleyebilecek kuvvetin, birbiriyle koordineli çalışabilecek sivil ve asker pek çok unsurdan oluşması gerekmektedir. Böyle bir kuvvette mobil, aynı istihbarat ortamından beslenen ve hareket eden, modern komuta kontrol sistemlerini kullanan çok yönlü birliklerin bulunması, asimetrik faaliyetlerde bulunmak üzere özel kuvvetlerin ve hedef ülke içerisindeki muhalif güçlerin kullanılması ve böylece hedef ülkenin bütün bölgelerinde sürekli aktif olan bir cephe oluşturulması gerekecektir. Ayrıca iletişim faaliyetlerinin ve araçlarının sürekli geliştirilmesinin, askerî gücün, istihbarat birimlerinin ve bilgi harbi/propaganda faaliyetlerinin koordineli kullanımının özellikle altı çizilmiştir.

6. Özellikle bilgi/iletişim alanının asimetrik etki oluşturabilme anlamında çok geniş imkânlar sunduğu ifade edilmektedir.

Rusya'nın yeni savaş doktrinin yerleşmesinde etkili olan bir diğer isim Korgeneral Alexander Vladimirov'dur. Vladimirov, "Savaşın Genel Teorisi” isimli kitabında savaşı bir "sosyal fenomen” ve "millî olarak var olmanın kritik bir parçası" olarak nitelendirmektedir. ${ }^{42}$ Böylece Vladimirov da savaşla barış arasındaki çizginin ortadan kalktığını teyit etmekte ve millî varlığın devam ettirilebilmesi için sürekli savaş hâlinin doğal bir durum olduğu sonucuna varmaktadır. Savaşla barış arasındaki çizgi, "güvensizlik" ve "savaş korkusu" ile dolu belirsiz bir geçiş sürecine dönüşmüştür. ${ }^{43}$ Vladimirov’un teorik çalışmasını inceleyen İsveç Ulusal Güvenlik Kolejinden Dr. Peter Mattsson’a göre yeni nesil savaşta askerî çatışma, en son ve nihai darbeyi vuran safhadır; ondan önce düşman ülkenin halkına, siyasi liderlerine ve sivil kuruluşlarına yönelik, bilgi harbi ve psikolojik harekâtla takviye edilen şaşırtıcı ve saptırıcı taarruzların yapılması gerekmektedir. ${ }^{44}$ Aslında savaş, ülkenin var olması için gerekli ve sürekli bir faaliyet hâline gelmekte, amacı ise yakıp yıkarak belli bir bölgenin hâkimiyetinin elde edilmesi değil politik, ekonomik ve kültürel etki altına alınması olmaktadır. Durum böyle olunca askerî güç, arzu edilen hedeflerin gerçekleştirilmesinde en etkili unsur olmaktan çıkmaktadır. Bunun yerine

40 Gerasimov, "The Value of Science".

41 Ibid.

42 Alexander Vladimirov, "General Theory of War Presented in RIAC", Russian International Affairs Council internet sitesi, 15 Nisan 2015, http://russiancouncil.ru/en/inner/?id_4=3539\#top-content (Erişim Tarihi 18 Temmuz 2015); Alexander Vladimirov, Osnovyi Obschey Teoryi Voynyi. Chast II Teoriya Natsyonalnoy Strategyi, Moskova, Universitet Sinergia, 2013.

43 Vladimirov, "General Theory of War".

44 Peter Mattsson, "Russian Military Thinking - A New Generation of Warfare”, Journal on Baltic Security, Cilt 1 No.1, 2015, s.61-70, http://www.baltdefcol.org/files/files/journal/JOBS01.pdf (Erişim Tarihi 15 Ağustos 2015). 
tercih edilen yeni strateji, dolaylı yöntemlerin kullanılmasıyla "organize kaos" ortamı oluşturmaktır. ${ }^{45}$ Dolaylı ve gizli yöntemlerle politik, ekonomik ve sosyal etki oluşturma faaliyetleri (kültürel savaş), şartlar arzu edilen şekilde geliştiğinde doğrudan taarruzlarla desteklenebilmektedir. ${ }^{46}$

Gerasimov ve Vladimirov tarafından özetlenen hususlar 26 Aralık 2014’te Rus Güvenlik Konseyi tarafından kabul edilen ve Putin tarafından onaylanan Rus askerî doktrinine ithal edilmiştir. Doktrin, modern çatışma ortamını "askerî güçle beraber politik, ekonomik faaliyetler, bilişim/propaganda faaliyetleri ile diğer askerî olmayan faaliyetlerin, özel kuvvetler ve/veya sivil halk kullanılarak karmaşık şekilde uygulandığı” bir ortam olarak tanımlamaktadır. ${ }^{47}$ Günümüzde karşılaşılması muhtemel krizlerde "dolaylı ve asimetrik hareket tarzlarının” kullanıldığı, bu hareket tarzlarının arasında (diğer yöntem ve araçlara ilave olarak) "halkın protesto potansiyelini suiistimal eden ve askerî olmayan yöntemlerin", "dış güçler tarafından desteklenen politik güçlerin ve sosyal hareketlerin” yer aldığı belirtilmektedir. ${ }^{48}$

Yeni Rus Askerî Doktrininin temelinde iki ana noktanın yattığı söylenebilir; "savaş her yerdedir” ve amaç (sadece) toprak işgal etmek değil, "arzu edilen etkileri” oluşturabilmektir. Letonya Ulusal Güvenlik Akademisinden Jānis Bērziņš, Peter Mattsson'ın değerlendirmelerinden faydalanarak Rusya’nın eski ve yeni savaş doktrinindeki farkları Tablo 1'de gösterildiği gibi özetlemektedir:

Tablo 1: Bērziņš ve Mattsson’a Göre Rusya’nın Savaş Doktrinindeki Değişim ${ }^{49}$

\begin{tabular}{|l|l|}
\hline \multicolumn{1}{|c|}{ Eski Doktrin } & \multicolumn{1}{c|}{ Yeni Doktrin } \\
\hline - Doğrudan taarruz & - Doğrudan etki \\
\hline - Düşmanın Yok Edilmesi & - Düşmanın İçeriden Çökertilmesi \\
\hline - Silahlarla Savaş & - Kültürel Savaş \\
\hline - Konvansiyonel Kuvvetler & $\begin{array}{l}\text { - Özel Kuvvetlerin ve Ülke İçindeki Muhalif Grupların } \\
\text { Kullanılması }\end{array}$ \\
\hline - Geleneksel Üç Boyutlu Harekât Ortamı & - Bilgi ve Algı Harbi \\
\hline - Doğrudan Temas & - Temassız Savaş \\
\hline - Bölümlendirilmiş Savaş & - Düşmanın Tüm Sistemlerinin Hedef Alınması \\
\hline - Fiziksel Ortamda Savaş & $\begin{array}{l}\text { - Fiziksel ortama ilave olarak insan zihninin ve siber } \\
\text { ortamın hedef alınması }\end{array}$ \\
\hline - Simetrik Etkilerin Kullanılması & $\begin{array}{l}\text { - Politik, ekonomik, bilgi/enformatik, teknolojik ve ekolojik } \\
\text { alanlarda asimetrik etkilerin kullanılması }\end{array}$ \\
\hline - Belirli Bir Zaman Diliminde Savaş & $\begin{array}{l}\text { - Bir ülkenin milli hayatında sürekli devam eden ve doğal } \\
\text { bir durum olan savaş }\end{array}$ \\
\hline
\end{tabular}

45 Ibid., s.66.

46 Ibid., s.67.

47 Olga Oliker, “Russia’s New Military Doctrine: Same as the Old Doctrine, Mostly”, The Washington Post, 15 Ocak 2015, http://www.washingtonpost.com/blogs/monkey-cage/wp/2015/01/15/russias-new-military-doctrine-same-as-theold-doctrine-mostly/ (Erişim Tarihi 07 Temmuz 2015).

48 Oliker, "Russia's New Military Doctrine”

49 Jānis Bērziņš, "Russia’s New Generation Warfare in Ukraine: Implications for Latvian Defense Policy”, National Defense Academy of Latvia Center for Security and Strategic Research Policy Paper, No.2, Nisan 2014, s.5, http://www.naa.mil. lv/ /media/NAA/AZPC/Publikacijas/PP\%2002-2014.ashx (Erişim Tarihi 18 Haziran 2015). 
Rus askerî uzmanlar Tchekinov ve Bogdanov ise Rus Savunma Bakanlığının yayımladığı dokümanları ve diğer ilgili Rus kaynaklarını inceleyerek yeni nesil savaşın neleri içerdiğini ve nasıl icra edileceğini ortaya koymaya çalışmıştır. Detayları çizilen strateji, Şekil 1'de özetlenen ve birbirini takip eden sekiz safhadan oluşmaktadır.

Şekil 1: Tchekinov ve Bogdanov’a Göre Yeni Savaş Stratejisi ${ }^{50}$

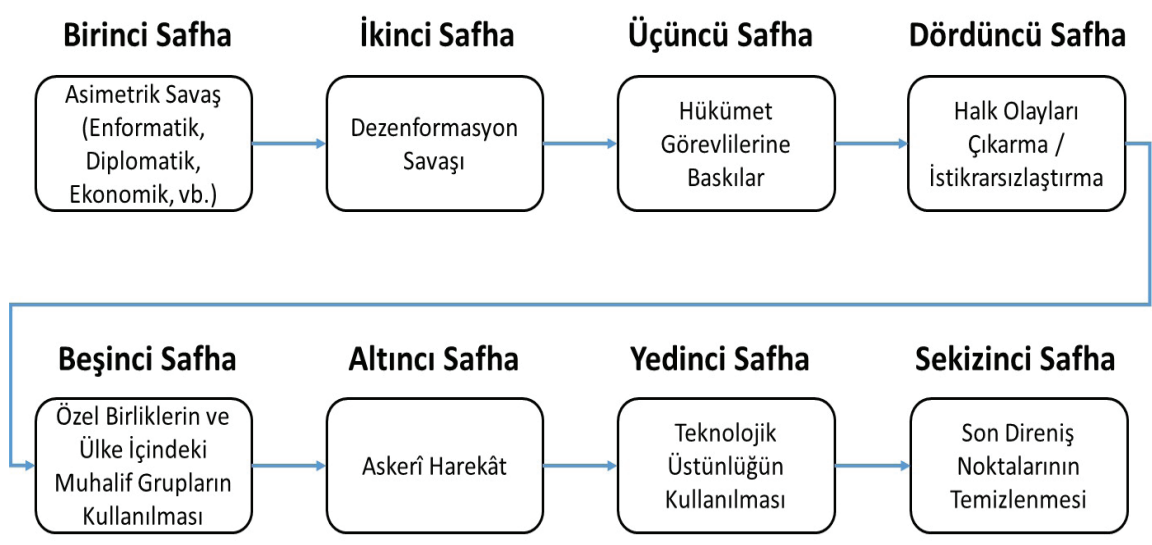

$\mathrm{Bu}$ teze göre askerî yöntemlerin kullanılmadığı asimetrik savaş (bilgi/enformatik, etik, psikolojik, ideolojik, diplomatik ve ekonomik yöntemlerin arzu edilen yönde politik, ekonomik ve askerî altyapı oluşturma planının bir parçası olarak kullanılması) ilk safhayı oluşturmaktadır. Takip eden dönemde diplomatik ve askerî kurumlardan, basın organlarından koordineli olarak sızdırılan yanlış bilgiler, emirler, direktifler ve talimatlar ile politik ve askerî liderlerin yanlış yönlendirilmesi için özel operasyonlar yapılmakta, aldatma ve rüşvet gibi yöntemlerle hükümet görevlileri ve askerî personelin görevlerini bırakması için baskı uygulanmaktadır. Dördüncü safha düşman ülkenin halkında huzursuzluğu artırmak için yapılan istikrarsızlaştırma faaliyetlerini; beşinci safha ise düşman ülkede uçuşa yasak bölge ilan ederek özel silahlı birliklerin silahlı muhalif gruplarla ortak olarak faaliyet göstermelerine imkân sağlanması olayların sivil halkın karıştırılmasını hedeflemektedir. Şartların olgunlaştırılmasını müteakip başlatılan askerî harekâtta teknolojik üstünlüğe sahip silahlar kullanılarak en kısa sürede ve en az zayiatla varsa hedef bölgenin ele geçirilmesi ve nihayet son direniş noktalarının ortadan kaldırılarak harekâtın tamamlanması hedeflenmektedir. ${ }^{51}$

Tchekinov ve Bogdanov'un belirttiği stratejinin her durumda uygulanabilir bir reçete olup olmadığı tartışmalıdır. Bu strateji, düşman ülke hükümet görevlilerine etki edebilme gücünün ve düşman ülke halkı içerisinde kendisine yakın halk kitlelerinin var olması gibi belli varsayımlara dayanmaktadır. Bu durum her şartta mümkün olmayabilir, ancak Ukrayna krizinde bu şartların pek çoğunun gerçekleştiği söylenebilir. Zira 2013'te başlayan ve 2014 yılında Kırım'ın Rus topraklarına katılması ile devam eden olaylar incelendiğinde gelişmelerin ve kullanılan yöntemlerin Tchekinov ve Bogdanov'un ortaya koyduğu yeni savaş stratejisi ile uyumlu olduğu görülmektedir.

50 S.G. Tchekinov ve S.A. Bogdanov, “The Nature and Content of a New-Generation War”, Military Thought: A Russian Journal of Military Theory and Strategy, Sayı 4, 2013, s.12-23, http://www.eastviewpress.com/Files/MT_FROM\%20 THE\%20CURRENT\%20ISSUE_No.4_2013.pdf (Erişim Tarihi 9 Mayıs 2015).

51 Ibid; ayrica bkz. Bērziņš, "Russia’s New Generation Warfare”, s.6. 


\section{Ukrayna Krizi}

Ukrayna eski lideri Viktor Yanukovich'in 21 Kasım 2013'te Avrupa Birliği (AB) ile ortaklık görüşmelerine katılmayacağını açıklaması sonrasında protesto gösterileri ile başlayan ve artan halk olayları neticesinde ülke yönetiminin el değiştirmesiyle farklı bir boyut kazanan Ukrayna krizi, "topyekûn" bir hibrit savaşın uygulandığı ilk örnek hâline gelmiştir. ${ }^{52}$ Krize doğrudan ve dolaylı olarak taraf olan uluslar ve uluslararası kuruluşlar, düzenli ordular ve simetrik yöntemler yerine farklı güçleri ve asimetrik yöntemleri tercih etmiş, kriz NATO-Ukrayna-Rusya üçgeninde çok yönlü devam etmiştir.

Ukrayna krizinde Rusya’nın politik hedefleri; Ukrayna'daki Batı yanlısı hükümeti yıpratmak ve uzun vadede düşürmek, kendisine yakın bir hükümeti işbaşında tutmak, bu olmazsa en azından Ukrayna'nın Batı'yla yakınlaşmasını engellemek, kendi ülke vatandaşlarının ve Rusça konuşan diğer ülkelerdeki halkın desteğini sağlamak, Batı halkları üzerinde ise "makul şüphe" oluşturmak olarak sıralanabilir. Bu hedefleri başarmak için Rusya, tüm millî güç unsurlarını uygun bir karışım hâlinde uygulamaktan kaçınmamıştır. Douglas Mastriano’ya göre Rus taktiği, sürekli bilgi harbi/psikolojik harekâtın uygulanmasını, kendine yakın halk kitlelerini kışkırtarak ülke içinde istikrarı bozmak için yürütülen gizli faaliyetleri, isyancılara karşı etkili önlemler alınmasını caydırmak üzere sınıra büyük bir askerî gücün yerleştirilmesini, insanî yardım adı altında sınırın ihlâl edilerek bu gruplara yardım sağlanmasını içermiş̧tir. ${ }^{53}$ Bütün bu faaliyetler icra edilirken hareket tarzlarında esnekliği sağlamak için belirsizlik stratejisi izlenmiş, son olarak belli bir bölgenin stratejik amaçla ele geçirilmesi sağlanmıştır. ${ }^{54}$

Kitleleri etkileme gücü ve özellikle düşman ülke halkı içerisinde etki altına alınabilecek gruplara ulaşabilme imkânı vermesi sebebiyle bilgi harbinin, hibrit savaşın temel bileşenlerinden biri olması doğal bir sonuçtur. Ukrayna krizinde hem NATO'nun, hem de Rusya'nın bilgi harbine (eski adıyla psikolojik harbe) büyük önem verdiği, ancak Rusya’nın daha hazırlıklı olduğu ve süreci daha iyi yönettiği sonucuna varmak yerinde olacaktır. Krizin başından itibaren Rusya tarafından bilgi harbi kapsamında gerçekleştirilen faaliyetler, Tchekinov ve Bogdanov tarafından Şekil 1'de birinci ve ikinci safha olarak belirtilen faaliyetlerle önemli benzerlik göstermektedir. Rus bilgi harbi sadece resmî açıklamalarla ve kendi halkıyla sınırlı kalmamış, çok boyutlu ve çok yönlü devam etmiştir. Bu dönemde Rus radyo, televizyon ve internet vasıtaları hem Rusça hem de İngilizce yayınlar yaparak Rusça konuşan halkın yanında uluslararası kitleleri hedeflemiştir. Kriz sırasında Rusya'nın yıllık iletişim harcamalarının 300 milyon avroya kadar çıktığı ifade edilmektedir. ${ }^{55}$ Stephen Komarnyckyj'ye göre Rus bilgi harbinin bileşenleri sadece devlet yayın organlarıyla sınırlı kalmamış, bağımsız görünümlü internet sitelerinden politik organizasyonlara, çeşitli yöntemlerle etki alanına alınmış politikacı, iş adamı ve şirketlerden Rus görüşlerini savunan gazeteci, yazar ve araştırmacılara, halkla ilişkiler şirketlerinden ücretli internet yorumcularına kadar uzanan geniş bir ağı kapsamıştır. ${ }^{56}$ Bahsi geçen

52 V. Usenko ve D. Usenko, "Russian hybrid warfare: what are effects-based network operations and how to counteract them”, Information Resistance: Ukrainian blog of the Center of Military-Political Studies and Euromaidan Press, Kiev, Ukrayna, 5 Kasım 2014, http://strataforum.org/ukraine-has-stood-with-us-both-in-iraq-and-afghanistan/ (Erişim Tarihi 06 Eylül 2015).

53 Douglas Mastriano, "Defeating Putin's Strategy of Ambiguity”, War on the Rocks, 6 Kasim 2014, http://warontherocks. com/2014/11/defeating-putins-strategy-of-ambiguity/ (Erişim Tarihi 06 Eylül 2015).

54 Ibid.

55 Mikelis Berzins, “JBANC Report on Russian Propaganda Efforts”, Estonian World Review, 15 Ağustos 2014, http:// www.eesti.ca/jbanc-report-on-russian-propaganda-efforts/article42927 (Erişim Tarihi 12 Eylül 2015).

56 Steve Komarnyckyj, "Putin's propaganda machine and how to smash it", Euromaidan Press, 26 Temmuz 2014, http:// 
internet yorumcularının devlet bütçesinden finanse edildiği ve ücretlerinin 30-40 bin ruble (yaklaşık $1.000 \mathrm{ABD}$ doları) olduğu, toplam maliyetlerinin aylık bir milyon ABD dolarına kadar çıktığı iddia edilmiştir. $^{57}$

Gerçekleştirilen yoğun bilgi harbi faaliyetleri, gizliliği her zaman sağlayamasa da Rus halkının ve gelişmeleri Rus kaynaklarından takip eden diğer ülkelerdeki grupların algılarını şekillendirmede etkili olmuştur. Kriz döneminde Rusya Devlet Başkanı Putin’i onaylayan Rusların oranı yüzde 80'in üzerinde seyretmiştir. ${ }^{58}$ Batı dünyasında ise farklı seslerin ve görüşlerin ortaya çıkması, en azından soru işaretlerinin oluşturulması hedeflenmiştir. Bu yöntem, "makul inkâr edilebilirlik" (plausible deniability) olarak isimlendirilmektedir. ${ }^{59}$ Rus kaynakları, Ukrayna'daki krizin tamamen bir iç çekişme olduğu, silah sevkiyatlarının özel şahıs veya gruplar tarafından yapıldığı, Rus askerlerinin değil silahlı yerel milislerin bölgede çarpıştığı, Rus ordusuyla bağlantılı olanların ise eski ordu personeli olduğu, aktif askerlerin görev almadığı tezlerini savunmuştur. Böylece Batı dünyasının ve NATO ülkelerinin bir bütün olarak hareket etmesini engellemeye, Batı kamuoyunda çatlaklar oluşturmaya çalışmıştır. Sonuçta uzaktan bakıldığında iki tarafın birbirine karşılıklı suçlamalar yönelttiği bir çekişme yaşanmıştır.

Rusya bir taraftan yoğun bilgi harbi faaliyetleri icra ederken diğer taraftan Tchekinov ve Bogdanov'un Şekil 1'de üçüncü safha olarak işaret ettiği şekilde devlet görevlilerini etkilemeyi hedeflemiştir. Örneğin Ukrayna askerlerine taraflarını değiştirdikleri takdirde rütbe ve seviyelerini koruma gibi sözler verildiği ve sonuçta Ukrayna askerlerinin yüzde 50'sinin Rus tarafına geçtiği rapor edilmiştir. ${ }^{60}$ Hedef ülkedeki halk olaylarının kullanılarak ülke yönetiminin istenen yönde hareket etmeye zorlanması, hibrit savaşın diğer önemli yöntemleri arasındadır. Şekil 1'de dört ve beşinci safhalar olarak ortaya koyulan bu faaliyetler kapsamında pek çok iddia ortaya atılmış, bu suçlamalar Rusya tarafindan hiçbir zaman kabul edilmemiş, ancak rütbe ve işaretleri sökülmüş Rus ordu üniformaları giyen askerlerin Doğu Ukrayna'da yerel milislerle birlikte çekilmiş fotoğrafları basın organlarında yerini almıştır. Rusya’nın kendine yakın yerel halkı yönlendirmek amacıyla danışmanlar ve özel ajanlar kullandığı, Rus Askerî İstihbarat Teşkilatı GRU'nun (Glavnoye Razvedyvatel'noye Upravleniye) 45'inci Spetsnaz alayına bu görevin verildiği iddialar arasındadır. ${ }^{61}$ Rus askerlerinin sivil halkın arkasında hareket ettiği ve onları yönlendirdiği iddiaları Kırım’da yaşanan halk olayları sırasında zirveye çımıştır. ${ }^{62}$

Rus yanlısı sivil halk kullanılarak başlatılan karşı devrim girişimi Kırım’da başarıya ulaşmış ve yarımadanın Rusya'ya eklenmesiyle sonuçlanmıştır. Rus askerlerinin Kırım’a girmesiyle Tchekinov ve Bogdanov'un işaret ettiği altı, yedi ve sekizinci safhalar da tamamlanmıştır. Rusya'nın bu ilhakı Ukrayna'ya karşı koz olarak kullanma ve Batı’ya yönelen yüzünü tekrar Rusya'ya çevirme niyetinin olması muhtemeldir, fakat Ukrayna'nın yeni yönetiminin böyle bir ihtimali düşünmeyeceği ortaya çıkmıştır. Takip eden dönemde Odesa'nın da içinde olduğu bazı bölgelerde karışıklığı artırma çabaları kayda değer bir sonuç vermemiştir. Bunun üzerine Rusya çabalarını Donbas bölgesi üzerinde

euromaidanpress.com/2014/07/26/putins-propaganda-machine-and-how-to-smash-it/ (Erişim Tarihi 11 Haziran 2015).

57 Usenko ve Usenko, "Russian hybrid warfare".

58 Bartkowski, "Nonviolent Civilian Defense”, s.8.

59 Bartkowski, “Nonviolent Civilian Defense”, s.8; Freedman, “Ukraine and the Art of Limited War”, s.23.

60 "Kyiv Negotiating Terms for Redeploying Ukrainian Military from Crimea to Mainland”, Interfax Ukraine, 24 Haziran 2014, http://en.interfax.com.ua/news/general/197552.html (Erişim Tarihi 21 Eylül 2015).

61 Eli Lake, “U.S. Eyes Russian Spies Infiltrating Ukraine”, The Daily Beast, 21 Haziran 2014, http://www.thedailybeast. com/articles/2014/03/21/u-s-eyes-russian-spies-infiltrating-ukraine.html (Erişim Tarihi 22 Mayıs 2015).

62 Bartkowski, "Nonviolent Civilian Defense", s.8. 
yoğunlaştırmıştır. Putin konuşmalarında bu bölge için tarihsel ismine atıfla "Novorossiya" ifadesini kullanmış ve 1922 yılında bu bölgenin Ukrayna' ya bağlanmasının yanlış olduğunu ifade etmiştir. ${ }^{63}$

Kırım'ın Rus topraklarına katılması ancak Ukrayna'nın diğer bölgelerinde aynı sonucun gerçekleşmemesi farklı yorumlara yol açmıştır. Bazı araştırmacılar, hibrit savaş tekniklerinin bazı durumlarda başarıya ulaşacağını, bazı durumlarda ise yetersiz kalacağını, Ukrayna krizinin her iki durumun örneğini gösterdiğini iddia etmektedir. ${ }^{64}$ Bazı araştırmacılar ise Donbas gibi bölgelerin ilhak edilmesinin, Rusya'nın daha geniş anlamdaki ulusal çıkarlarının zararına olacağını, bu durumda Ukrayna’nın geri kalanının tamamen kaybedileceğini, ayrıca Rusya’nın tekrar yayılmacı ve işgalci bir güç olarak görüleceğini, böylece bütün dünyanın Rusya'ya karşı birleşme ihtimalinin artacağını düşünmektedir. Dolayısıyla Rusya’nın daha fazla toprak kazanma yerine Moldova ve Gürcistan'da olduğu gibi "dondurulmuş çatışma” ortamının daha fazla çıkarlarına hizmet edeceğini düşünerek hareket ettiği değerlendirmeleri yapılmaktadır. ${ }^{65}$

Halk olaylarının kullanılması konusunda Rusya’nın kendi ülkesini harp ortamının dışında tutmadığı görülmüştür. Kendi halkı içerisinde ortaya çıkabilecek protestolara karşı önlem almak ve halk desteğini artırmak isteyen Rusya, "nashi” (bizimkiler) adını verdiği ve hükümet taraftarı gençlerin katıldığı bir halk hareketi oluşturmuştur. ${ }^{66}$ Putin, "nashi” leri iç kamuoyunda desteğe ihtiyacı olduğu durumlarda kullanmaya başlamış, organize edilen mitinglere "Putingi" (Putin-mitingi) adı verilmiştir. ${ }^{67}$ Putingiler 2012 yılında muhalefet parlamento seçimlerinin hileli olduğunu iddia ettiği zaman ya da 2014'teki barış protestoları sırasında da devreye sokulmuştur. ${ }^{68}$

Hibrit savaş kapsamında kullanılan ve şiddet içermeyen diğer bir önemli yöntem ise insanî yardım faaliyetleridir. Krizlerin ortaya çıkardığı insani durumları kullanan bu yöntemin eleştirilmesi ya da engellenmesi karşı tepki oluşturacaktır. Halk olaylarının Ukrayna’nın doğusundaki Donbas bölgesine yayılmasından sonra Rusya, isyancıların etkin olduğu bölgeye insanı yardım konvoyları göndermeye başlamıştır. Bu tür şiddet içermeyen faaliyetler, karşı tarafı çıkmaza sokmayı amaçlayan etkin yöntemlerdir. $\mathrm{Bu}$ sebeple bazı araştırmacılar şiddet içermeyen halk olaylarının ve insani yardım faaliyetlerinin kullanılmasını "çıkmaz hareketi” veya "gösterisi" (dilemma action/demonstration) olarak nitelemektedir. ${ }^{69}$ Philippe Duhamel, çıkmaz oyununu karşı tarafı açmaza sokan bir taktik olarak tanımlamaktadır: "Eğer faaliyetin sürdürülmesine izin verilirse, icra eden taraf iddiasını her yöne duyurmuş ve otoriteyi sarsmış olur. Eğer güç kullanılarak bu olaylar bastırılırsa, güç kullanan taraf hem kendini izah edilmesi zor bir duruma sokar, hem de halk bastırılan grupların iddiaları hakkında daha da fazla bilgi sahibi olur” ${ }^{70}$ Karşı tarafın, insani yardım adı altında yapılan faaliyetlere herhangi bir müdahalede bulunması suiistimal edilebilecek ve tepki görecek bir konudur. Hiçbir müdahale olmaması ise, sınırının bilfiil delinmesi,

63 Ivan Necheprenko, “Donbass' Roots of Violent Division: Geography, History, Culture”, The Moscow Times, 20 Nisan 2014, http://www.themoscowtimes.com/news/article/donbass-roots-of-violent-division-geography-history-culture/ 498447.html (Erişim Tarihi 15 Temmuz 2015).

64 Mark Galeotti, “'Hybrid War' and 'Little Green Men': How It Works, and How It Doesn't”, E-International Relations. 16 Nisan 2015, http://www.e-ir.info/2015/04/16/hybrid-war-and-little-green-men-how-it-works-and-how-it-doesnt/ (Erişim Tarihi 12 Ağustos 2015).

65 Freedman, "Ukraine and the Art of Limited War", s.13,14.

66 Bartkowski, "Nonviolent Civilian Defense”, s.8.

67 Ibid.

68 Ibid.

69 Majken Jul Sørensen ve Brian Martin, “The Dilemma Action: Analysis of an Activist Technique”, Peace \& Change, Cilt 39 No.1, Ocak 2014, s.73-100, http://onlinelibrary.wiley.com/doi/10.1111/pech.12053/epdf(Erişim Tarihi 28 Temmuz 2015).

70 Philippe Duhamel, The Dilemma Demonstration: Using Nonviolent Civil Disobedience to Put the Government between a Rock and a Hard Place, Minneapolis, MN., Center for Victims of Torture, 2004. 
topraklarında başka bir ülkenin faaliyette bulunması, gelen konvoyların ve insanların farklı amaçlara da hizmet edebilmesi anlamına gelecektir. Nitekim Rus insanî yardım konvoylarının gelirken beraberlerinde silah, giderken de Ukrayna endüstriyel tesislerinden çalınan malzemeleri götürdüğü iddia edilmiştir. ${ }^{71}$

Hibrit savaş konsepti, çok geniş bir spektrumdaki aktörlerin sinerji oluşturabilecek şekilde koordineli kullanılmasını öngördüğ̈nden yönetim/komuta güçlüğünü beraberinde getirmektedir. Ukrayna krizi sırasında Rus aktörler arasında bu koordinenin büyük oranda başarıldığı söylenebilir. İstihbarat birimleri başta olmak üzere devletin tüm birimlerinin ve özel unsurların yüksek bir eşgüdüm içerisinde çalıştı̆̆ görülmüştür. Rus Askerî İstihbaratı GRU Kırım’da askerî birlikler desteğini alarak etkin olmuş, Rus gönüllülerle yardım malzemelerini Doğu Ukrayna’ya sokmuş, bu arada muhtemelen Donbas bölgesindeki en sert birliklerden olan ve Ukrayna yönetimine isyan eden Vostok birliğini desteklemiştir. ${ }^{72}$ Federal Güvenlik Birimi (FSB eski KGB) daha çok Ukrayna'nın doğusunda faaliyette bulunmuş, Ukrayna istihbaratına sızarak ordudan ayrılmaları körüklemiş ve Kiev'in planlarını takip etmiştir. ${ }^{73}$ Rus İç İşleri Bakanlığı (MVD) muhtemel ajan olabilecek kişileri ve kaynakları belirlemek için Ukrayna içindeki bağlantılarını kullanmış, askerî birlikler sınırda konuşlanarak gözdağı vermiştir. Bütün bunlarla eş zamanlı olarak Rus medyası ve diplomatik kaynakları Kiev'deki hükümeti kanun dışı ilan etmiş ve aşırı güç kullanmakla suçlamış, bilgisayar korsanları Ukrayna bankalarına ve hükümet internet sitelerine saldırılar düzenlemiştir. ${ }^{74}$

Ukrayna krizinin başladığı anlardan itibaren sıranın eski Varşova Paktı üyesi olan Doğu Avrupa ülkelerine ve özellikle de Baltık Cumhuriyetlerine gelmesi ihtimali en tedirgin edici ihtimallerden biri olmuştur. Bu ülkeler, NATO koruması altına girerek kendilerini büyük oranda güven altına aldıklarına inanmışken hibrit savaşta uygulanan taktikler, NATO şemsiyesinin bazı durumlarda yetersiz olabileceği endişesini doğurmuştur. NATO’nun sağlamayı taahhüt ettiği ortak güvenlik sistemi, asıl olarak Washington Anlaşması'nın beşinci maddesi kapsamında ifade edilen üye ülkelerden birine silahlı tecavüz durumunda devreye girmektedir. İttifakın bu konuda dünyada kendini ispatlamış bir güç oluşturduğu açıtır. Oysa Ukrayna Krizi, modern krizlerde beşinci madde ile kapsanandan çok daha karmaşık tehditlerin ülkelere yönlendirilebileceğini göstermiştir.

Ukrayna Krizi, yeni nesil savaşın tipik bir örneği hâline gelmiştir, ancak başarılı bir örneği olduğu yönünde acele karar vermemek uygun olacaktır. Genel kanaat, krizin ne Rusya, ne Batı, ne de Ukrayna tarafından tam bir başarıyla yönetilmediği, her taraf için olumlu ve olumsuz sonuçlar doğurduğu yönündedir. ${ }^{75}$ Örneğin Rusya açısından olumlu olabilecek gelişmeler değerlendirildiğinde, kritik önem taşıyan Kırım'ın ilhakı gerçekleşmiş, Ukrayna’nın AB ve NATO'ya daha fazla yakınlaşması, en azından resmî ortaklık kurması önlenmiştir. Ancak diğer yönden Baltık ve Doğu Avrupa ülkelerindeki eski Sovyet korkusu yeniden canlanmış, halk arasında ve devlet kurumlarında bilinçlenme artmış, benzer Rus faaliyetlerine (özellikle Rusça konuşan kesimlerin kullanılarak başlatılabilecek sivil halk olaylarına) karşı önlemler alınmaya başlanmış, enerji bağımlılığını yıkma konusunda arayışlar hızlanmıştır. Batı yanlısı bir hükümetin iktidara gelmesiyle Ukrayna'nın Batı’ya yakınlaşması yavaşlatılmış, ancak Rusya’ya yakınlaşma ihtimali hemen hemen kalmamıştır. Daha önce Rusya’yı ortak olarak gören Batı ülkeleri, Ukrayna krizinden sonra stratejik bir problem olarak görmeye başlamıştır.

\footnotetext{
71 Freedman, "Ukraine and the Art of Limited War", s.16.

72 Galeotti, "Hybrid War".

73 Ibid.

74 Ibid.

75 Freedman, "Ukraine and the Art of Limited War", s.1.
} 
NATO ve $A B$ açısından değerlendirildiğinde krizin olumsuz tarafları daha fazla göze çarpmaktadır. En başta İttifak'ın krize hazırlıksız yakalandığı ve Rusya karşısında etkin bir politika izleyemediği görülmektedir. Rusya, Ukrayna'nın toprak bütünlüğüne açıkça tecavüz anlamına gelecek durumlardan kaçınmış, harekâtı temel olarak bilgi harbi boyutunda ve Ukrayna'nın iç dinamiklerini kullanarak sürdürmüştür. NATO, Rus taktikleri karşısında genelde reaktif kalmış, propaganda faaliyetlerinin etkisini kıramamış, sonuçta süreci yöneten Rusya olmuştur. Ancak bu olumsuzluklara rağmen krizin NATO birlikteliğinin pekişmesi ve ortak savunma ihtiyacının teyit edilmesi gibi konularda faydası olduğu iddia edilebilir. Özellikle Soğuk Savaş sonrası dönemde varlığı sorgulanmaya başlayan NATO'nun üye ülkeleri çok daha somut bir düşmanla karşı karşıya kaldıklarını görmüş, hem İttifak, hem de onu güçlendirme çabaları daha fazla meşruiyet kazanmıştır. Ukrayna açısından değerlendirildiğinde ise gelişmeler görünüşte ülkenin NATO ve AB'yle bütünleşme çabaları sekteye uğramıştır, ancak halkın önemli bir bölümü tarafından Rus yanlısı politika izlemekle suçlanan yönetimin değişmesine yol açmıştır.

Sonuç olarak Rusya, Ukrayna krizinde askerî ve sivil unsurları beraber kullanan, asimetrik uygulamaları içeren bir taktik uygulamıştır. En fazla faydalandığı araç, kendine yakın etnik gruplar olmuş, çeşitli vasıtalarla bu grupların faaliyetlerini yönlendirmiş ve koruma altına almıştır. Ukrayna’nın belli bir bölümünü kendi topraklarına katarken diğer bir bölümünde ise krizin devam etmesini sağlamıştır. Böylece kesin fakat sınırlı bir sonuca ulaşmak yerine "dondurulmuş çatışma” olarak tabir edilen yaklaşımı benimsemiş, Ukrayna’nın kendi etki alanından çıkıp düşman olarak benimsediği Batı’ya yaklaşmasını sınırlandırmıştır. Bu strateji, "belirsizlik savaşı” olarak da adlandırılmaktadır. ${ }^{76}$

\section{Değerlendirme ve Sonuç}

Bugün uluslararası ortam, yeni olmayan ancak farklı bileşenlerle daha aktif ve etkili olarak uygulanan yeni nesil bir savaşla yüzleşmektedir. Asimetrik etki üzerine yoğunlaşan ve diplomatik, ekonomik, sosyal, enformatik, vb. alanlardaki araçların ortak politik hedef doğrultusunda koordineli kullanılmasını hedefleyen bu savaş şekli, sıcak çatışma kurallarını ve belki de ihtiyacını değiştirmekte, barışla savaş arasındaki geçişi belirsiz hâle getirmektedir. Bugün hangi faaliyetlerin ülkeler arasında süregelen diplomatik ve politik mücadele, hangi faaliyetlerin ise savaş kapsamına gireceği tartışmalı hâle gelmiştir.

Yeni nesil savaşın en temel karakteristiği, kullanılan araçların sayısının ve çeşitliliğinin çoğalması ve hepsinin koordineli olarak en üst seviyede belirlenen politik hedefin gerçekleştirilmesi için kullanılmasıdır. Gelişen teknolojiyle beraber politik ve uluslararası ortamda artan aktörler ve gittikçe daha karmaşık hâle gelen ekonomik, finansal ve sosyal bağlantılar, bir taraftan düşmanın suiistimal edilebilecek taraflarını, diğer taraftan amaca ulaşmak için kullanılabilecek araçların ve yöntemlerin kombinasyonlarını eşi görülmemiş seviyede artırmıştır. Dolayısıyla düzenli kuvvetlerin kullanılması ve/veya silahlı çatışma, hibrit savaşın sadece bir alt kümesini oluşturmaktadır. Politik amaçlara ulaşmak için kullanılabilecek aktörlerin ve yöntemlerin ileride daha da artması kaçınılmazdır. Durum böyle olunca geleceğin çatışmalarında hibrit savaşların önemli yer tutması, yapılacak mücadelelerde başarıyı getirenin ise büyük askerî güçten ziyade karmaşık ortamları yönetebilme yeteneğinin olması yüksek bir olasılıktır. Bununla beraber, çok geniş alana yayılan aktörlerin sinerji oluşturacak şekilde koordineli kullanılabilmesi, yönetim ve komuta kontrol zorluklarını beraberinde getirmektedir. Bu tür güçlükler, hibrit savaşın sonuca ulaşma etkisini azaltabilmektedir.

76 Mastriano, "Defeating Putin's Strategy". 
Rus doktrininde belirtildiği gibi hibrit savaşın harekât ortamı insan zihnidir; dolayısıyla bilgi harbi ve psikolojik harekât, hibrit savaşın temel araçlarıdır. ${ }^{77} \mathrm{Bu}$ araçlar özellikle hedef ülkedeki etnik, dini ve/veya kültürel yakınlığı olan halk kitlelerini hedef almaktadır. Yönlendirilen sivil halk olayları, karşı tarafın politik zaaflarından faydalanmakta ve ülkeyi istikrarsızlaştırarak istenen yönde hareket etmesini veya en azından istenmeyen yönde hareket etmemesini sağlama amacı gütmektedir. $\mathrm{Bu}$ noktadan hareketle hedef ülkede etnik ve kültürel yakınlığı olan halkın bulunmasının, o ülkenin hibrit tehditlerden etkilenme ihtimalini artırdığı sonucuna varmak tutarlı olacaktır.

Hibrit yöntemlerin kullanıldığı krizlerde askerî güç doğrudan kullanılmayabilir, ancak yine de önemini korumaktadır. Olayların tırmanıp sıcak savaşa dönmesi hâlinde karşı taraf üzerinde etkili olamayacak bir ülkenin hibrit savaşı yönetmesi imkân dışı olacaktır. Lawrence Freedman, hibrit savaşın başarı ihtimalini, icra eden tarafın "krizi tırmandırmaya hazır olduğu" yönünde oluşturulan algının geçerliliğine bağlamaktadır. ${ }^{78}$ Rusya, Ukrayna’da açık bir şekilde krizi gidebileceği yere kadar tırmandırmaya hazır olduğunu göstermişken NATO ve Batı’nın aynı seviyede istekli olmadığı görülmüştür. Bu gözlemden hareketle Freedman, toprak üzerine olan çatışmalarda hâlâ en etkili gücün askerî güç ve yüksek ateş gücü olduğunu, bunların kullanılmasının veya kullanılmasalar bile kullanılmaya hazır olunmasının belirleyici olduğunu iddia etmektedir. ${ }^{79}$

Hibrit savaşın gerçek anlamda fayda sağlayıp sağlamayacağı konusunda bir sonuca ulaşmak için henüz çok erken olduğu değerlendirilmektedir. Her şeye rağmen bu konudaki farkındalığı artırmak, muhtemel uygulama alanları konusunda dikkatli olmak için şarttır, zira mevcut ve gelecekte karşılaşılabilecek muhtemel krizlerde benzer taktiklerle karşılaşılması ihtimali yüksektir. Bugün yaşanan pek çok krizin bu tanıma uyduğu, ülkelerin bu kapsama giren faaliyetler yürüttüğü iddia edilebilir. Hibrit savaş yaklaşımındaki temel düşüncenin savaşla barış arasındaki çizginin giderek incelmesi hatta ortadan kalkması olduğu değerlendirildiğinde, bu savaşın sürekli uygulanıyor olması ihtimali yüksektir ve önlem alınması ihtiyacı daha belirgin bir şekilde ortaya çıkmaktadır.

77 Bērziņš, "Russia’s New Generation Warfare”, s.5.

78 Freedman, "Ukraine and the Art of Limited War", s.11.

79 Ibid., s.12. 


\section{Kaynakça}

ABD Ulusal Güvenlik Direktifi No.108 (National Security Decision Directive No.108), 12 Ekim 1983, Federation of American Scientists, http://fas.org/irp/offdocs/nsdd/nsdd-108.pdf (Erişim Tarihi 17 Eylül 2015).

Bachmann, S.D. ve H.Gunneriusson. "Hybrid Wars: The 21st Century's New Threats to Global Peace and Security”, Scientia Militaria - South African Journal of Military Studies, Cilt 43 Say1 1, 20 Mayıs 2015, s. 77-98.

Bartkowski M. "Nonviolent Civilian Defense to Counter Russian Hybrid Warfare", Beyaz Kitap Gov1501, The Johns Hopkins University Center for Advanced Governmental Studies, Washington D.C., 2015, http:// advanced.jhu.edu/academics/graduate-degree-programs/global-security-studies/program-resources/ publications/white-paper-maciej-bartkowski/ (Erişim Tarihi 19 Eylül 2015).

Bērziņš J. “Russia’s New Generation Warfare in Ukraine: Implications for Latvian Defense Policy”, National Defense Academy of Latvia Center for Security and Strategic Research Policy Paper No:02, Nisan 2014, http://www.naa.mil.lv/ /media/NAA/AZPC/Publikacijas/PP\%2002-2014.ashx (Erişim Tarihi 18 Haziran 2015).

Berzins M. “JBANC Report on Russian Propaganda Efforts”, Estonian World Review, 15 Ağustos 2014, http:// www.eesti.ca/jbanc-report-on-russian-propaganda-efforts/article42927 (Erişim Tarihi 11 Haziran 2015).

Boot, Max ve Michael Doran, “Political Warfare”, ABD Dış İlişkiler Konseyi Politika Geliştirme Kağıdı No:33 (Policy Innovation Memorandum No. 33), Haziran 2013, http://www.cfr.org/wars-and-warfare/politicalwarfare/p30894 (Erişim Tarihi 14 Mart 2016).

Booth, Ken. Theory of World Security, Cambridge, Cambridge University Press, 2007.

Creveld, Martin van. The Transformation of War, New York, The Free Press, 1991.

Deep A. "Hybrid War: Old Concept, New Techniques", Small Wars Journal, 2 Mart 2015, http://www.isn.ethz. ch/Digital-Library/Articles/Detail/?lng=en\&id=189134\#_edn1(Erişim Tarihi 27 Temmuz 2015).

Duhamel P. The Dilemma Demonstration: Using Nonviolent Civil Disobedience to Put the Government between a Rock and a Hard Place, Minneapolis, MN., Center for Victims of Torture, 2004.

Duyvesteyn, Isabelle ve Jan Angstrom (der.). Rethinking the Nature of War, London, Frank Cass, 2006.

Echevarria II, Antulio J. Clausewitz and Contemporary War, Oxford University Press, 2007.

Filkins D. "The Shadow Commander", The New Yorker, 30 Eylül 2013, http://www.newyorker.com/ magazine/2013/09/30/the-shadow-commander (Erişim Tarihi 1 Temmuz 2015).

Freedman L. "Ukraine and the Art of Limited War", Survival: Global Politics and Strategy, Cilt 56 No.6, Aralık 2014 - Ocak 2015, s. 7-38.

Galeotti M. "Putin, Ukraine and Asymmetric Politics", bne Intellinews, 14 Nisan 2014, http://www.intellinews. com/comment-putin-ukraine-and-asymmetric-politics-500399277/? source $=$ russia\&archive $=$ bne $($ Erişim Tarihi 14 Mart 2016).

Galeotti M. “'Hybrid War' and 'Little Green Men': How it Works, and How it Doesn't”, E-International Relations. 16 Nisan 2015, http://www.e-ir.info/2015/04/16/hybrid-war-and-little-green-men-how-it-works-andhow-it-doesnt/ (Erişim Tarihi 12 Ağustos 2015).

Galeotti M. “The 'Gerasimov Doctrine' and Russian Non-Linear War”, In Moscow's Shadows (internet blog), 6 Temmuz 2014, https://inmoscowsshadows.wordpress.com/2014/07/06/the-gerasimov-doctrine-andrussian-non-linear-war/ (Erişim Tarihi 6 Ağustos 2015).

Gerasimov V. "The Value of Science in Prediction”, Military-Industrial Kurier, Cilt 8 No.476, 27 Şubat 2013, http://www.vpk-news.ru/articles/14632 (Erişim Tarihi 23 Haziran 2015).

Grant G. "Hybrid Wars", Government Executive, Cilt 40 Sayı 5, 1 Mayıs 2008, http://www.govexec.com/ magazine/features/2008/05/hybrid-wars/26799/ (Erişim Tarihi 14 Haziran 2015).

Hoffman F. Conflict in the 21st Century: The Rise of Hybrid Wars, Potomac Institute for Policy Studies, Arlington, VA, Aralık 2007, http://www.potomacinstitute.org/images/stories/publications/potomac hybridwar_0108.pdf (Erişim Tarihi 15 Haziran 2015). 
Hoffman F. “Hybrid Warfare and Challenges”, Joint Forces Quarterly, Say1 52, 2009, s. 34-39.

Hoffman F. "On Not-So-New Warfare: Political Warfare vs Hybrid Threats", War on the Rocks, 28 Temmuz 2014, http://warontherocks.com/2014/07/on-not-so-new-warfare-political-warfare-vs-hybrid-threats/ (Erişim Tarihi 23 Temmuz 2015).

Jones M. "Fighting This Nation of Liars to the very end: The German Army in the Franco-Prussian War, 18701871", Williamson Murray ve Peter R. Mansoor (der.), Hybrid Warfare: Fighting Complex Opponents from the Ancient World to the Present, Cambridge, Cambridge University Press, 2012, s. 171-198.

Kaldor, Mary. New and Old Wars: Organized Violence in a Global Era, Oxford, Polity Press, 1999.

Karaosmanoğlu, A.L. "Yirmibirinci Yüzyılda Savaşı Tartışmak: Clausewitz Yeniden”, Uluslararası İlişkiler, Cilt 8, Say1 29 (Bahar 2011), s. 5-25.

Keegan, John. A History of Warfare, New York, Vintage Books, 1993.

Kennan, George. ABD Dışişleri Bakanlığı Politika Planlama Kağıdı No: 269 (Policy Planning Staff Memorandum), 4 Mayıs 1948, http://academic.brooklyn.cuny.edu/history/johnson/65ciafounding3.htm (Erişim Tarihi 14 Mart 2016).

Komarnyckyj S. "Putin's propaganda machine and how to smash it", Euromaidan Press, 26 Temmux 2014, http:// euromaidanpress.com/2014/07/26/putins-propaganda-machine-and-how-to-smash-it/.

Lacey J. “Conquering Germany: A Province Too Far”, Williamson Murray ve Peter R. Mansoor (der.), Hybrid Warfare: Fighting Complex Opponents from the Ancient World to the Present, Cambridge, Cambridge University Press, 2012, s. 2-42.

Lake E. “U.S. Eyes Russian Spies Infiltrating Ukraine”, The Daily Beast, 21 Mart 2014, http:/ /www.thedailybeast. com/articles/2014/03/21/u-s-eyes-russian-spies-infiltrating-ukraine.html (Erişim Tarihi 22 Mayıs 2015).

Landler M. ve R.G. Michael. "NATO Chief Warns of Duplicity by Putin on Ukraine”, The New York Times, 8 Temmuz 2014, http://www.nytimes.com/2014/07/09/world/europe/nato-chief-warns-of-duplicity-byputin-on-ukraine.html?_r=1 (Erişim Tarihi 12 Haziran 2015).

Mansoor, P.R. "Introduction: Hybrid Warfare in History", Williamson Murray ve Peter R. Mansoor (der.), Hybrid Warfare: Fighting Complex Opponents from the Ancient World to the Present, New York, Cambridge University Press, 2012, s. 1-8.

Mastriano D. "Defeating Putin's Strategy of Ambiguity”, War on the Rocks, 6 Kasım 2014, http:/ /warontherocks. com/2014/11/defeating-putins-strategy-of-ambiguity/ (Erişim Tarihi 06 Eylül 2015).

Mattsson P. "Russian Military Thinking - A New Generation of Warfare", Journal on Baltic Security, Cilt 1, No.1, 2015, s. 61-70, http://www.baltdefcol.org/files/files/journal/JOBS01.pdf (Erişim Tarihi 15 Ağustos 2015).

Maxwell, David. "Taking a Spoon to a Gunfight", War on the Rocks, 2 Nisan 2014, http://warontherocks. com/2014/04/taking-a-spoon-to-a-gunfight/ (Erişim Tarihi 14 Mart 2016).

McDermott R. “Gerasimov Unveils Russia’s 'Reformed' General Staff”, Eurasia Daily Monitor, Cilt 11 No.27, 11 Şubat 2014, http://www.jamestown.org/single/?tx_ttnews[tt_news]=41951\&no_cache=1\#.VghFNZc49k (Erişim Tarihi 4 Temmuz 2015).

Murray W. "The American Revolution: Hybrid War in America's Past", Williamson Murray ve Peter R. Mansoor (der.), Hybrid Warfare: Fighting Complex Opponents from the Ancient World to the Present, Cambridge, Cambridge University Press, 2012, s. 72-103.

Münkler, Herfried. The New Wars, Cambridge, Polity Press, 2005.

NATO StratCom CoE Raporu, "Analysis of Russia's Information Campaign Against Ukraine", NATO Stratejik İletişim Mükemmeliyet Merkezi (NATO StratCom COE) Raporu, Riga, Latvia, 2014, http://www. stratcomcoe.org/ /media/SCCE/NATO_PETIJUMS_PUBLISKS_29_10.ashx (Erişim Tarihi 25 Ağustos 2015). 
Necheprenko, I. “Donbass' Roots of Violent Division: Geography, History, Culture”, The Moscow Times, 20 Nisan 2014, http://www.themoscowtimes.com/news/article/donbass-roots-of-violent-division-geographyhistory-culture/498447.html (Erişim Tarihi 15 Temmuz 2015).

Oliker O. "Russia’s New Military Doctrine: Same as the Old Doctrine, Mostly”, The Washington Post, 15 Ocak 2015, http://www.washingtonpost.com/blogs/monkey-cage/wp/2015/01/15/russias-new-militarydoctrine-same-as-the-old-doctrine-mostly/ (Erişim Tarihi 07 Temmuz 2015).

Perry, Bret. "Non-Linear Warfare in Ukraine: The Critical Role of Information Operations and Special Operations”, Small Wars Journal, 14 Ağustos 2015, http://smallwarsjournal.com/printpdf/27014 (Erişim Tarihi 14 Mart 2016).

Smith E.A. "Effects-Based Operations: Applying Network Centric Warfare in Peace, Crisis, and War", US DoD Command and Control Research Program (CCRP), 2003, http://www.au.af.mil/au/awc/awcgate/ccrp/ ebo_smith.pdf (Erişim Tarihi 29 Ağustos 2015).

Sørensen M.J. ve B. Martin. “The Dilemma Action: Analysis of an Activist Technique”, Peace \& Change, Cilt 39 No.1, Ocak 2014, s. 73-100. http://onlinelibrary.wiley.com/doi/10.1111/pech.12053/epdf (Erişim Tarihi 28 Temmuz 2015).

Strachan, Hew ve Andreas Herberg-Rothe (der.). Clausewitz in the Twenty-First Century, Oxford, Oxford University Press, 2007.

Sun-Tzu. The Art of War, Bölüm 4/12, (çeviri Sonshi Grup), https: / /www.sonshi.com/original-the-art-of-wartranslation-not-giles.html (Erişim Tarihi 4 Eylül 2015).

Tchekinov, S.G. ve S.A. Bogdanov. "The Nature and Content of a New-Generation War”, Military Thought: A Russian Journal of Military Theory and Strategy, Sayı 4, 2013, s.12-23, http://www.eastviewpress.com/ Files/MT_FROM\%20THE\%20CURRENT\%20ISSUE_No.4_2013.pdf (Erişim Tarihi 9 Mayıs 2015).

Thornton R. Asymmetric Warfare: Threat and Response in the 21st Century, Cambridge, Polity Press, 2007, s. 1-8.

Usenko, V. ve D. Usenko. "Russian hybrid warfare: what are effects-based network operations and how to counteract them”, Information Resistance: Ukrainian blog of the Center of Military-Political Studies and Euromaidan Press, Kiev, Ukrayna, 5 Kasım 2014, http://strataforum.org/ukraine-has-stood-with-us-bothin-iraq-and-afghanistan/ (Erişim Tarihi 06 Eylül 2015).

Vladimirov A. "General Theory of War Presented in RIAC”, Russian International Affairs Council internet sitesi, 15 Nisan 2015, http://russiancouncil.ru/en/inner/?id_4=3539\#top-content (Erişim Tarihi 18 Temmuz 2015).

Warden J.A. "The Enemy as a System”, Airpower Journal, Cilt 7, No:1, Bahar 1995, s. 40-55 http://www. airpower.maxwell.af.mil/airchronicles/apj/apj95/spr95_files/warden.htm.

Wijk R.D. "Hybrid Conflict and the Changing Nature of Actors", Julia Lindley-French, Yvew Boyer (der.), The Oxford Handbook of War, Oxford, Oxford University Press, 2012, s. 358-372.

Yamaguchi N. "An Unexpected Encounter with Hybrid Warfare: The Japanese Experience in North China, 1937-1945”, Williamson Murray ve Peter R. Mansoor (der.), Hybrid Warfare: Fighting Complex Opponents from the Ancient World to the Present, Cambridge, Cambridge University Press, 2012, s. 225-253. 